\title{
The Construction and Application of the WeChat- based Translation Teaching Model
}

\author{
http://dx.doi.org/10.3991/ijet.v11i09.6112 \\ Lemin Shen \\ Zhejiang Wanli University, Ningbo, China
}

\begin{abstract}
Since its introduction in the 2011, WeChat has become an indispensable communication tool. At present, this application provides opportunities to expand foreign language teaching and helps develop mobile learning. To improve the translating ability of students, this thesis maximizes the advantages of WeChat and presents a completely new teaching model called "WeChat-based Translation Teaching Model." By adopting constructivism theory, a oneyear teaching reform experiment was conducted (from Feb. 2015 to Jan 2016) on the translation teaching model based on WeChat. Results show that this teaching model can increase the number of students who read and acquire knowledge, promote communication and interaction between teachers and students, as well as cultivate the autonomous learning ability of students. By demonstrating the positive significance of the application of WeChat in this context, this research can serve as a useful reference material for translation teaching in colleges and universities.
\end{abstract}

Index Terms - WeChat, Translation teaching model, internet

\section{INTRODUCTION}

Multimedia network teaching has continued to expand in recent years. Meanwhile, the reference entitled The Requirements for Undergraduate Translation Teaching (Trial Edition) serves as an important guide to the development of translation teaching in Chinese colleges and universities in the new century. The guideline states that "we should make full use of internet, and apply modern technics into teaching, thus to explore a new teaching model for cultivating talents" [1]. Zhong Weihe, president of the Guangdong University of Foreign Studies, also mentioned that "in the big data era, exploring new teaching methods, especially for modern information technologies, are teachers' responsibility" [2]. Domestic scholars hold the same view and believe that "mobile learning is the future of foreign language teaching [3] ." The NMC Horizon Report: 2013 anticipated that mobile learning will become the mainstream teaching model in the Information Age [4]. As part of mobile learning, WeChat gained popularity among students. In the past three years, WeChat set off a "micro-wave" of the Internet revolution through its unique functions and the strong momentum of development. This application (or app) facilitates knowledge exchange through online meeting and video communication, which were not possible in the past. Until August, 2016, more than 800 million people in China used WeChat to communicate, interact, and socialize with others synchronously and asynchronously [5]. Thus, studying the application of the WeChat-based Translation Teaching Model is meaningful in this Information Age.

\section{STATE OF THE ART}

Local and foreign researches on translation teaching mainly concentrated on describing the conditions, discussing the training model proposed, and explaining the teaching methods of translation. The main features of college English translation teaching in China are described below.

First of all, research on mobile learning is still in its early stages. Dye defined mobile learning as "a help of mobile computing devices that can be carried out at any time and any place. Mobile learning using mobile computing devices must be effectively render the learning content and provide two-way communication between teachers and learners" [6]. At present, mobile learning has gained popularity among young students around the world[7-8]. Elias argued that the learning style for the new generation has transformed from distance learning and e-learning to mobile learning [9]. The majority of research in China focused on the application of mobile learning in college English teaching. Meanwhile, studies on translation teaching have yet to be conducted.

Second, studies on WeChat or WeChat teaching are limited even though the app is now commonly used in China. By searching the China Knowledge Resource Integrated Database using the keywords "WeChat" and "Teaching," only 28 essays appeared, and 12 of these were about English teaching. Nevertheless, the number of essays increased annually, indicating that domestic researchers are becoming more interested in WeChat. Still, many of these studies only adopt a macroscopic view on WeChat-based teaching. For example, the majority of the research are feasibility studies [10-11] or micro-education case studies of the app [12-14]. Very few of these works are related to translation teaching.

Thirdly, Translators and educators recognize the importance of focusing on the practice ability of students, but feasible measures are lacking. According to Cai "the purpose of translation training is to teach students how to learn. By using multimedia tools, teaching resources, community resources, we try to form a teaching cycle system which combines studying in class and out of class together, and combines comments from teachers and out campus practicum together, as well as combines practice with research. Thus, we create a multi-dimensional teaching atmosphere, and stimulate the potential of students' learning motivation and self-improvement" [15-16]. However, most translation courses in universities cannot provide students with sufficient opportunities to practice their English language. Given that determining an appropriate solution is crucial, the current paper presents a new translation teaching model. By adopting constructivism theory, WeChat is used to cultivate the practical ability of stu- 
dents to further promote translation teaching and improve the translation ability of students.

The remainder of this paper is organized as follows: Section 3 establishes the translation teaching model based on WeChat and provides a detailed description about this teaching process, Section 4 analyzes the research results and discusses the applicability of the model through case studies, and Section 5 summarizes the conclusions.

\section{Methodology}

Based on Burn's action research theory [17], 75 students in 2014 and 86 students in 2015 were selected as respondents. This experiment was carried out from February 2015 to January 2016. To test its feasibility, the teaching model was conducted twice for two different groups of students. Based on the administrative division of classes, we selected English classes 1 (44 students) and English Classes 2(38 students) as the experimental class and English 3(42 students) and English Class 4(37 students) as the control class randomly. The course "Chinese Culture Translation Study" was set as the experimental course. The objectives of this experiment are as following: 1.To testify whether WeChat is helpful in improving learners' translation ability. 2. To construct a new teaching model based on WeChat.

\section{A. Research design}

Based on WeChat, the reverse translation teaching model focuses on the comparison of the new model with the traditional translation model to determine the differences, existing problems, and corresponding countermeasures. Through the WeChat-based translation teaching method, a new learning platform is established, which encourages students to learn independently according to their own situations. The learning process is monitored, and evaluation methods are modified during this process. Both the experimental class and the control class were taught by the same teachers using different teaching methods. The control classes were taught by utilizing traditional methods, whereas the experimental classes were taught using WeChat-based methods. At the end of this six-month experiment, a survey was conducted among students, and a comparative analysis of their achievement was carried out. In addition, different evaluation methods were adopted on the two different classes. The evaluation methods of the experimental class focus on process performance, whereas the evaluation methods of the control class focuses on the summative evaluation. The evaluation methods are described below.

1. Experimental class grade = class assignments $(20 \%)+$ exercises $\quad(15 \%)+$ classroom performance $(15 \%)+$ interactive communication $(10 \%)+$ WeChat resources contribution $(20 \%)+$ WeChat information quiz $(20 \%)$

2. Control class grade $=$ class attendance $(10 \%)+$ classroom performance $(10 \%)+$ exercises $(10 \%)+$ mid-term exam $(20 \%)+$ final exam $(50 \%)$

\section{B. Introduction to the WeChat-based Translation Teaching Model}

Constructivist theory states that students learn from cognitive activities and should not be considered as mere passive recipients of external stimuli and knowledge[18]. Learning always occurs in the interaction between students and their learning environment (including learning resources, teachers, students, and media). Based on constructivism theory, a WeChat-based translation teaching model that combines the main functions of the app is proposed and developed. The WeChat-based translation teaching model aims to cultivate the translation ability of students and provide more practical opportunities by maximizing the features of this app. The new translation teaching model is summarized as "translation practice first $\longrightarrow$ students generalize the basic skills by themselves $\longrightarrow>$ students generalize basic theory by themselves $\longrightarrow$ teacher deliver a lecture $\longrightarrow$ make a comparison between authority theory and students conclusion $\rightarrow$ expositive teaching of theory $\longrightarrow$ expositive teaching of basic skills $->$ and similar examples translation practice again." This teaching method can maximize translation skills and provide opportunities to practice learning. To some extent, the method can also develop the critical thinking skills of students and allow them to act as real interpreters. The platform was constructed as follows.

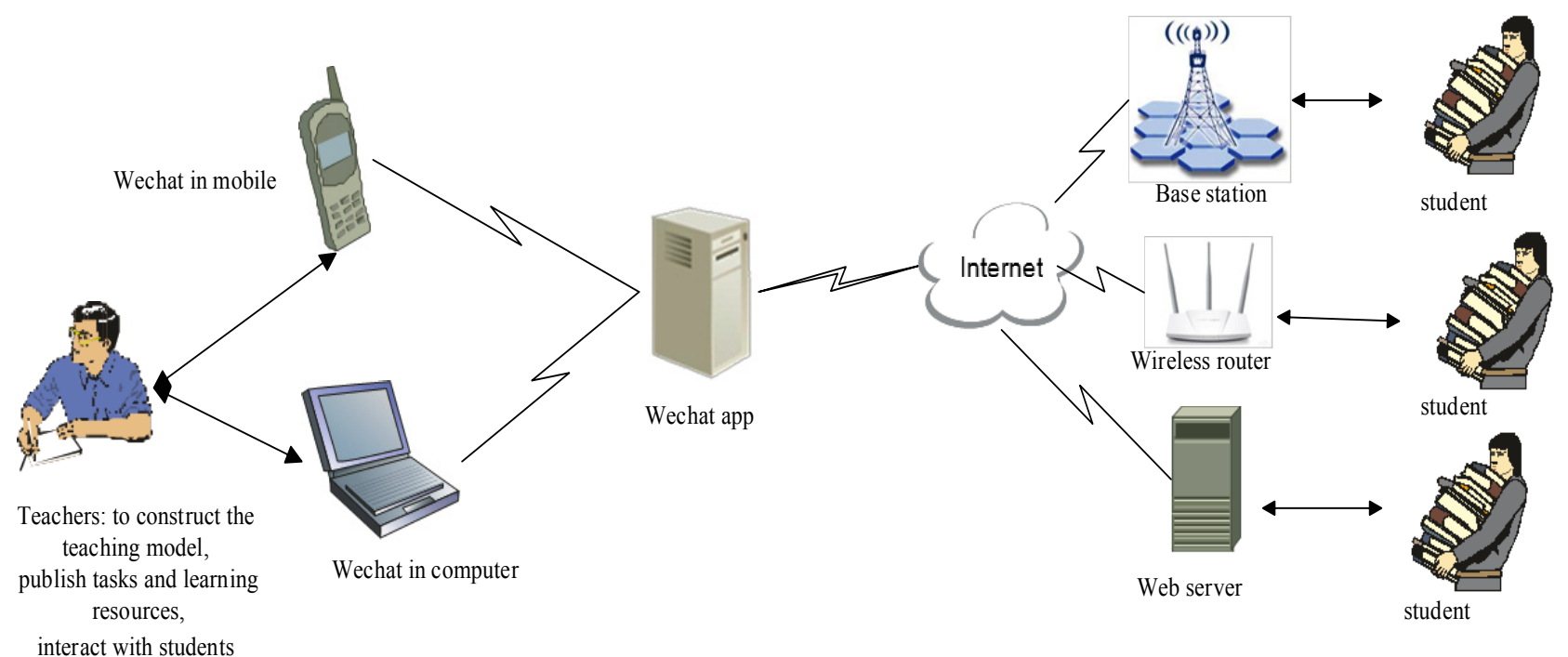

Figure 1. WeChat-based Translation Teaching Model 
At the beginning of the semester, teachers open WeChat in advance and require all the students from the experimental class to join a group chat using their real names. Shared moments include eight sections, namely, "theory prior to sharing," "skills guide," "exercises before class," "practice after class," "resource sharing," "daily news," and "group chat." In the teaching process, teachers publish the related content in the moments or group chat and require students to focus on or provide corresponding replies.

Second, teachers deliver the source translation examples in the "exercise before class" section and require students to participate. Source translation cases are usually presented in paragraphs, and the teaching process is adjusted based on length and difficulty. Before the class, teachers do not teach their students nor read the textbook for techniques and theories (e.g., note-taking skills, short-term memory skills of interpretation, and reduced amplification for word skills). The students must complete the translation practice within the allotted time and send their translation to the teachers using WeChat. This phase is the point of initial contact with relevant translations. Students will encounter many challenges in this process, such as taking down notes, adjusting sentence order, and memorizing original content. These experiences can enhance their problem-solving skills and increase their interest to learn. By using WeChat, teachers easily collect students' problems and reorganize their groups. Thus, teachers ask students to translate examples, to which they are likely to respond. Teachers can easily determine the weaknesses of their students. In this case, teachers can "adjust the task or provide adequate training to help students to master these skills"[19].

Third, students can apply their skills and the theoretic principles that they learned in translating with the guidance of their teachers. Teachers can then publish authoritative translation skills and theoretical principles in the "theories sharing" section and require students to read, independently discriminate, and finally establish consensus. Thus, students are required to practice translating by using the skills and theories taught by their teachers. By comparing the two translation versions that they produced, all the students are encouraged to participate in group discussions and demonstrate the guiding role of theory and techniques.

Last but not the least, through "exercise after class" section, students are required to practice again. In the "interaction" section, an entire class could participate in discussions and rate the best examples. To enhance the initiative and enthusiasm of students, their evaluation results are counted towards the total score. Teachers join the group chat and help students determine their learning difficulties and weaknesses. Teachers will add supplementary reading materials to the "resource sharing" section for students to read, in the process of which the latter are able to consolidate the ideas they learned.

The process is described as follows (Figure 2).

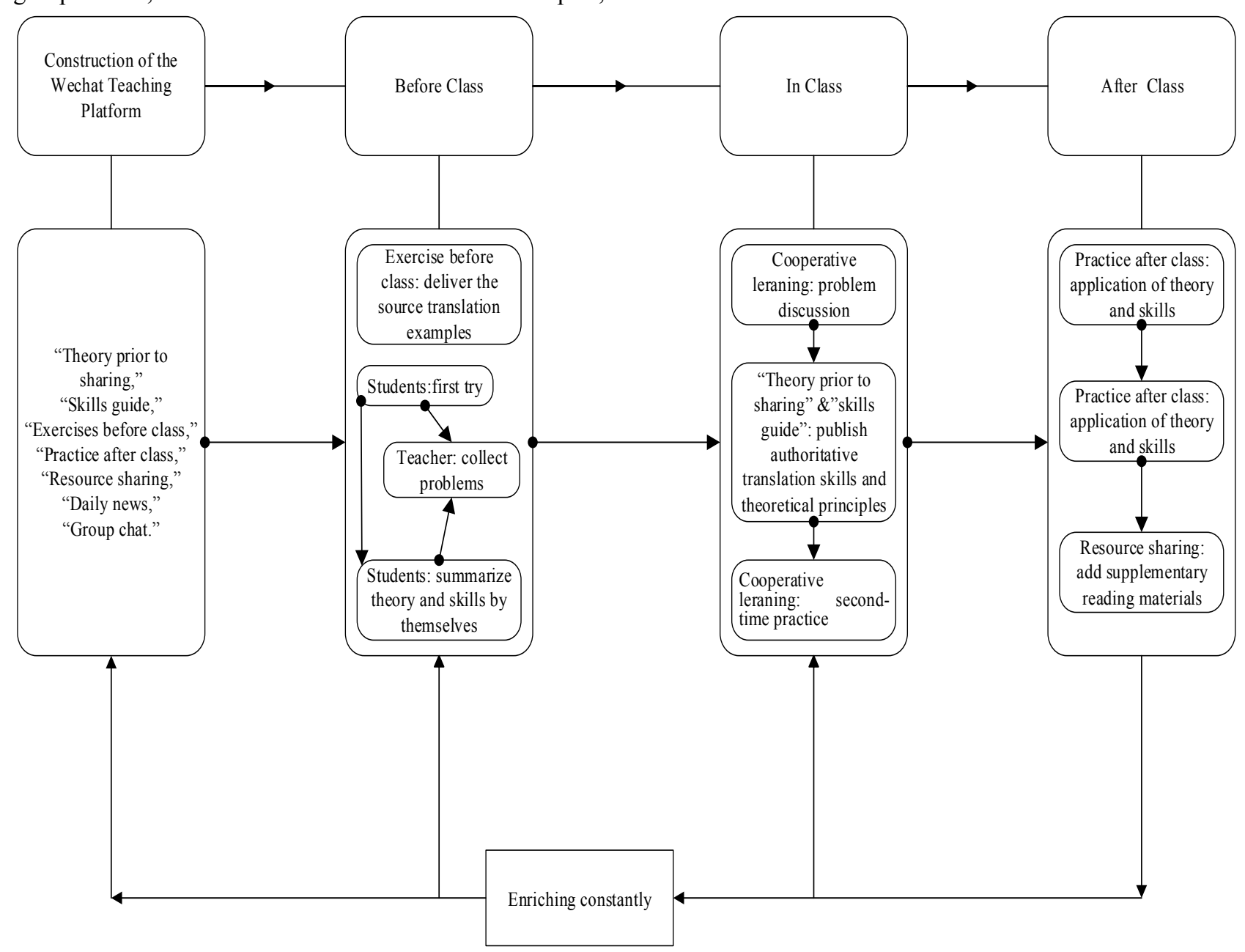

Figure 2. The flow diagram of the WeChat-based translation teaching model 
SHORT PAPER

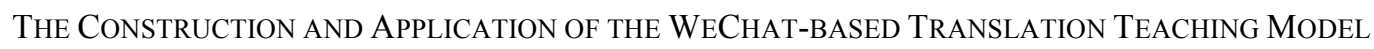

TABLE I. SURVEY ON THE USERS' SATISFACTION WITH THE “WECHAT-BASED TRANSLATION TEACHING MODEL”

\begin{tabular}{|c|c|c|c|c|c|}
\hline Questions & Strongly agree & Agree & Neutral & Disagree & Strongly disagree \\
\hline 1. WeChat teaching is easy to use. & $\begin{array}{c}49 \\
59.8 \%\end{array}$ & $\begin{array}{c}24 \\
29.2 \%\end{array}$ & $\begin{array}{c}6 \\
7.3 \%\end{array}$ & $\begin{array}{c}3 \\
3.7 \%\end{array}$ & $\begin{array}{c}0 \\
0 \%\end{array}$ \\
\hline 2. The teaching model is better than the traditional one. & $\begin{array}{c}33 \\
40.2 \%\end{array}$ & $\begin{array}{c}44 \\
53.7 \%\end{array}$ & $\begin{array}{c}3 \\
3.7 \%\end{array}$ & $\begin{array}{c}2 \\
2.5 \%\end{array}$ & $\begin{array}{c}0 \\
0 \%\end{array}$ \\
\hline $\begin{array}{l}\text { 3. The teaching model has a positive influence on } \\
\text { cultivating your translation ability. }\end{array}$ & $\begin{array}{c}46 \\
56.1 \%\end{array}$ & $\begin{array}{c}26 \\
31.7 \%\end{array}$ & $\begin{array}{c}7 \\
8.5 \%\end{array}$ & $\begin{array}{c}3 \\
3.7 \%\end{array}$ & $\begin{array}{c}0 \\
0 \%\end{array}$ \\
\hline $\begin{array}{l}\text { 4. The teaching model has a positive influence on } \\
\text { cultivating learner autonomy. }\end{array}$ & $\begin{array}{c}23 \\
28 \%\end{array}$ & $\begin{array}{c}54 \\
65.8 \%\end{array}$ & $\begin{array}{c}2 \\
2.5 \%\end{array}$ & $\begin{array}{c}3 \\
3.7 \%\end{array}$ & $\begin{array}{c}0 \\
0 \%\end{array}$ \\
\hline 5. The teaching model must be applied widely. & $\begin{array}{c}35 \\
42.7 \% \\
\end{array}$ & $\begin{array}{c}36 \\
43.9 \%\end{array}$ & $\begin{array}{c}11 \\
13.4 \%\end{array}$ & $\begin{array}{c}0 \\
0 \%\end{array}$ & $\begin{array}{c}0 \\
0 \%\end{array}$ \\
\hline
\end{tabular}

TABLE II. ANALYSIS OF STUDENTS’ ACHIEVEMENTS

\begin{tabular}{|l|c|c|c|c|}
\hline \multicolumn{1}{|c|}{ Class } & $\begin{array}{c}\text { Average score before } \\
\text { experiment }\end{array}$ & $\begin{array}{c}\text { Average score after } \\
\text { experiment }\end{array}$ & $\begin{array}{c}\text { Highest score after } \\
\text { experiment }\end{array}$ & $\begin{array}{c}\text { Lowest score after } \\
\text { experiment }\end{array}$ \\
\hline Experimental class & 72.77 & 82.75 & 95 \\
\hline Control class & 72.81 & 76.6 & 76 \\
\hline
\end{tabular}

\section{RESUlt ANALYSIS AND DiSCUSSION}

To determine the effect of the WeChat-based translation teaching model, a survey was conducted at the end of each semester. The corresponding analysis results are as presented in Table I.

\section{A. Satisfaction Survey}

The students' satisfaction survey includes WeChat teaching, translation teaching method, teaching effect, and other views. The questionnaire adopted a Likert Scale. The survey results are shown in Table I.

Table III indicates that this teaching model is deemed acceptable by the majority of students, and that early $89 \%$ of the students believe that using WeChat is a more effective teaching method than other multimedia teaching approaches. Smith and Craig pointed out that "multimedia teaching model has break through the limitation of space and time, and has constructed an open teaching space. Thus students can be anywhere in the campus, at any time, to learn anything they want to learn in the suitable time" [20]. WeChat facilitates learning "anywhere and anytime." Thus, many students prefer WeChat-teaching. Nearly94\% students thought that the WeChat-based translation teaching model is better than the traditional teaching methods. In the interviews, students believe that this teaching model mobilizes their learning initiative and enthusiasm and allows them to become the master of their class. Meanwhile, teachers act as "organizers" and "guides" in the teaching process. These new roles allow students to realize their responsibility and spend substantial time and energy on preparing and studying for their course. Approximately $87.8 \%$ of the students believe that this teaching model is more conducive to the cultivation of translation ability and that this teaching model is very new. According to some students, "When looking at the moments, it is unavoidable to read the message which teachers sent, and my vocabulary just increased in this process" and "To translate first makes me know my weakness, so in the class, I will listen with target, I am not an armchair strategist anymore."

\section{B. Experimental analysis of the final exam of students}

At the end of the semester, an analysis was carried out on the experimental class and the control class. The results of the analysis are presented in Table II.
Table II shows that no significant difference exists between the two classes before the experiment. However, late in the experiment, the average score of the experimental class is 6.15 times higher than that of the control group. When the highest and lowest scores are compared, the score of the experimental class proved to be higher than that of the control group, which is 7 points and 14 points, respectively. These achievement gaps indicate that the learning efficiency of the experimental class is significantly higher than that of the control group. The result indicates that this WeChat-based translation teaching model can improve the translation ability of students.

\section{Analysis from the perspective of the practical ability of students}

The analysis of the final exam may not fully indicate the effectiveness of this teaching mode. Statistical tests were conducted on the social practice and certification of students. Unlike that of the students in the control class, the translation ability of students from the experimental class were significantly improved. The number of students who participated in various translation examinations, such as Shanghai Advanced Interpretation, National Translation Certificate, and CATTI, also increased. The statistical tests indicate that the number of participants increased by $27 \%$ in 2014 . A total of 83 students took an exam, in which 43 were from the experimental class. The number of participants increased by $50 \%$ in 2015. A total of 89 students took another exam, in which 56 were from the experimental class. Twenty-eight students passed Shanghai Interpretation of Intermediate level, and 17 of these students came from experimental class. Five students were certified by the Shanghai Interpretation of Advanced Level, and three of them were from the experimental class. An increasing number of students aim to demonstrate the level of their translation ability by taking exams. These results demonstrate the effectiveness of the WeChat-based translation teaching model.

What is more, students' social skills are enhanced by this teaching model. In 2015, the students participated in Zhejiang Investment and Trade Negotiation, International Tennis Competitions, and International Music Festival as assistant interpreters, and their interpreting skills were recognized by the organizers. The employers regarded them as "professional translators." According to the students, they overcame stage fright through their 
practices in WeChat teaching. Two companies signed a cooperation agreement with our college because of the excellent performance of the students. Our university became an event translation partner of the said companies.

In 2016, the students of the experimental class attended the "First LSCAT (Language Service Competence Assessment and Training in China) interpretation competition" and won second price in Zhejiang Province, whereas the students from the control group lost in the preliminary contest.

\section{Analysis From the perspective of students, evaluation of teaching effect}

In the author's university, teaching evaluation uses the anonymous online evaluation, in other words, it can perfectly see students attitude towards this teaching model. In the two semesters, the assessment score of the experimental class consistently ranked among the highest in the school, and the averaged score of the evaluation is 96.520(out of 100). While for the control class, the score is 94.21. As a result, we made a comparison with students' comment of two different classes, we found that students from the experimental class frequently used the word as "interaction, diversity, interesting", some of them expressed like that "this course can mobilize my learning initiative, thought-provoking". These results coincide with our expectation.

\section{CONCLUSIONS}

The data analysis and discussion indicate that the WeChat-based translation teaching model helps improve the translation ability of students, fosters their interest in learning, as well as stimulates their motivation and initiative to enhance the learning autonomy. The main conclusions are described below.

(1) Teachers should develop and improve their ability to use new information technologies. In the big data era, teachers should learn and maximize mobile learning, particularly WeChat.

(2) This teaching model is actually based on the "interpreter-oriented" training idea. Each theme's translation practice requires students to perform like a real interpreter. During discussions and practice sessions, the students are exposed to an actual interpreting environment, which enhanced their translation ability. This approach equipped them for their future professional careers after graduation.

(3) This teaching model modifies the manner of selecting teaching materials. Teachers traditionally use a textbook for an entire semester and apply it step by step. By utilizing WeChat, teachers can keep various materials according to their teaching plan and add updated translation materials. This study can address the demands to cultivate translation skills. However, the model is limited by the research subjects. The participants in the study are independent college students. Thus, the design of WeChat teaching focuses the application of this approach and not on theory. Further studies are needed to improve its applicability in top universities.

\section{REFERENCES}

[1] MOE. The Requirements for Undergraduate Translation Teaching (Trial Edition).Beijing: Foreign Language Press, 2011.
[2] Zhong Weihe. "Translation teaching requirement in higher education." Chinese Translation Journal, vol.32, no.3, pp.20-24, June 2011.

[3] Gui Qingyang. "M-leraning: the future of Chinese foreign language leaning." Computer-Assisted Foreign Language Education, no.3, pp. 67-72, June 2003.

[4] Johnson, L. Et al. The NMC Horizon Report 2013. Austin, Texas: The New Media Consortium, 2013.

[5] CAICT. "The influence report of WeChat 2016." Beijing: China Association of Information Communications and Technology, 20160324.

[6] Aleksander Dye et al. "Mobile education:a glance at the Future". http://www.nettskolen.com/forskning/mobileeducation.pdf,2014/0 $\underline{8 / 17}$.

[7] Barreh. "A framework for mobile learning for enhancing learning in higher education." Malaysian Online Jounal of Education Technology, vol.3, no.3, pp.1-9, 2015.

[8] Al Zahrani Hasan. "A critical meta-analysis of mobile learning research in higher education." Journal of Technology Studies, vol.41 (S1), pp. 74-89, Fall 2015.

[9] Tanya Elias. "Universal instructional design principles for mobile learning." The International Review of Research in Open and Distance Learning, vol.12, no.2, pp. 143-156, February 2011.

[10] Yang,S., \& Chen,I. . "A social network-based system for supporting interactive collaboration in knowledge sharing over peer-topeer network." International Journal of Human-Computer Studies, vol.66 (S1), pp. 36-50, January 2008. http://dx.doi.org/10.1016/j.i jhcs.2007.08.005

[11] Bergmann, J., \& Sams, A.. Flip your classroom: reach every student in every class every day. Washington, DC: International Society for Technology in Education. 2012.

[12] Xu Meidan. "The influence of WeChat in college teaching." Eeducation Research, vol.35, no.11, pp. 89-94, November 2014.

[13] Liao Qingsheng. "The application of Wechat in college English teaching." Journal of Language and Literature, no.9, pp.121-123, September 2015.

[14] Jiang Hongmei. "The application of Wechat in college English teaching." Journal of Shunde Polytechnic, vol.11, no.2, pp.52-54, Summer 2013.

[15] Liu Hepin. "A discussion on the principle and teaching methods of College Translation Teaching." Chinese Translation Journal, vol.30, no.6, pp. 34-41, December 2009.

[16] Cai Xiaohong. "Study on the interactive teaching mode of interpretation peroformance." Chinese Translation Journal, vol.29, no.4, pp.45-48, August 2008.

[17] Anne Burns. Doing A ction Research in English Language Teaching: A Guide for Practitioners.Beijing: Foreign Language Teaching and Research Press, 2011.

[18] Fox R. "Constructivism examined.”Oxford Review of Education, vol.2(S1),pp. 23-35, March 2001: http://dx.doi.org/10.1080/03054 980125310

[19] Hubbard, P.. "Learner training for effective use of CALL". In:s.Fotos\& C. Browne (Eds), New Perspectives on CALL for Second Language Classrooms. Mahwah, NJ: Lawrence Erlbaum. 2004.

[20] KM Smith, H Craig." Enhancing Learner Autonomy through CALL: A new model in EFL curriculum design." CALICO Journal, no.11, pp.252-260, 2013. http://dx.doi.org/10.11139/cj.30.2.2 $\underline{52-278}$

\section{AUTHOR}

Lemin SHEN is a Teacher of the Foreign Languages College, Zhejiang Wanli University, Ningbo, 315100 China. Her research interests include translation teaching and internet-based teaching. (slmyss@zwu.edu.cn).

The author is grateful for the support provided by the Social Science Association of Ningbo (No. G16-ZX24), and National Educational Information and Technology Institute (No. 156242537). Submitted 07 August 2016. Published as resubmitted by the author 11 September 2016. 